\title{
NO. 89
}

FEBRUARY

2018

\section{KEY POINTS}

- Cambodia's demographic dividend offers great opportunities, but its human resource base remains largely low-skilled. It will be critical for Cambodia not only to improve education and technical and vocational training for young people entering the labor market, but also to upgrade the skills of the existing workforce.

- Technical and vocational education and training (TVET) is indispensable to socioeconomic development as it produces the skilled workers and technicians an evolving and modernizing labor market needs.

- The National TVET Policy will guide the government's skills development strategies and coordinate all parties involved.

- The policy presents a clear vision, goals, objectives, and strategies to develop human resources with the competencies and skills that promote socioeconomic development today and in the future.
ISBN 978-92-9261-084-5 (print) ISBN 978-92-9261-085-2 (electronic) ISSN 2071-7202 (print) ISSN 2218-2675 (electronic)

Publication Stock No. BRF189240 DOI:http://dx.doi.org/10.22617/BRF189240

\section{Cambodia's New Technical and Vocational Education and Training Policy}

This policy brief summarizes Cambodia's new Technical and Vocational Education and Training (TVET) Policy 2017-2025, formally approved by the government on 16 June 2017. The brief intends to help promote understanding of the policy among the wide range of TVET stakeholders including ministries, training institutions, employer and employee associations, development partners, civil society organizations, and Cambodia's youth. The new policy will guide the formulation and implementation of strategies for skills development and will facilitate better coordination among those involved in skills development in Cambodia. The policy was developed through a consultative process with technical assistance from the Asian Development Bank (ADB) ${ }^{2}$ with the goal of transforming and modernizing Cambodia's skills development system to better serve new labor force entrants, existing workers, and Cambodia's future development.

\section{DEMOGRAPHIC TRENDS PRESENT A WINDOW OF OPPORTUNITY...}

Cambodia's demographic transition has opened a demographic window of opportunity wherein a large proportion of the population is of working age, either getting ready to enter the labor market, or already in it. The population structure in the figure shows the relatively large age cohort comprising those ages 20-24 years. The largest age cohort, ages $10-14$, will be joining the workforce in just a few years.

Whether Cambodia can turn this demographic window of opportunity into development impact is a challenge. According to the most recent labor force survey in 2012, only about $28 \%$ of Cambodia's working age population of 10.7 million had completed secondary education, and only $1 \%$ attended vocational training, while $2 \%$ attended university. It will be critical for Cambodia's continued socioeconomic development not only to encourage increased access to technical training for new labor market entrants but also to upgrade the skills and competencies of the existing workforce. The new TVET policy aims to guide such initiatives in a more systematic manner.

Royal Government of Cambodia. 2017. National Technical and Vocational Education and Training Policy 2017-2025. Phnom Penh.

2 ADB. 2015. CDTA8942-CAM: Strengthening Capacity Development for National Skills Development. Manila. 


\section{Population Pyramid of Cambodia, 2008 and 2013}

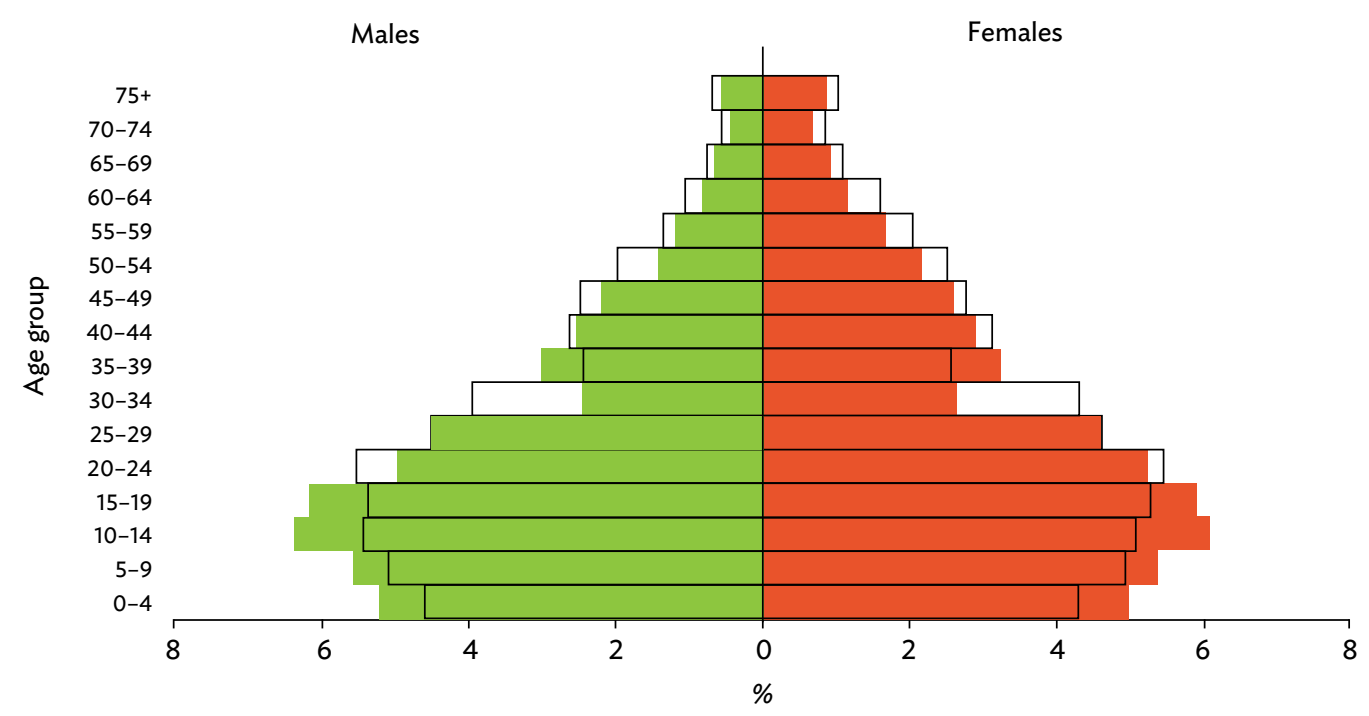

2008 population

Source: Cambodia Inter-Censal Population Survey 2013 (CIPS 2013).

\section{...BUT THE CURRENT TECHNICAL AND VOCATIONAL EDUCATION AND TRAINING SYSTEM FACES SEVERAL CHALLENGES}

Government and development partner efforts have achieved noticeable improvement in skills development over the past decade, but there are still some critical challenges:

- The quality of the TVET system does not respond to labor market demands due to: (i) a lack of a quality assurance system,

(ii) outdated training methods and equipment, (iii) trainers lack direct industry experience, and (iv) poor training infrastructure.

- There is still a lack of value attributed to TVET and negative perceptions caused by low enrolment in TVET. Young people still view TVET as a second option, or as education meant for the poor, marginalized groups, or school dropouts.

- The financial resources for the TVET system are limited. Training to build a skilled workforce from a low base requires a huge investment. The government cannot do this alone. Innovative financing that includes contributions from the private sectorin other words, the firms and enterprises that stand to benefitis essential.

- There is still limited acceptance of TVET qualifications across other education streams. Despite the existence of a Cambodian Qualifications Framework, linkages are still limited between the general education and TVET streams, and there is a lack of joint effort in developing TVET trainers and sharing learning materials and labor market information among the responsible ministries.

- Employers tend to note limited foundation and soft skills among first job seekers. Graduates tend to lack foundation skills in such areas as reading, writing, mathematics, computing, communication, teamwork, problem solving, customer relations, and foreign languages.

\section{STRENGTHENING THE POLICY FRAMEWORK FOR INDUSTRIAL DEVELOPMENT, EMPLOYMENT, AND SKILLS}

The government developed an extensive medium-term multisector policy framework to guide industrial development, employment, and skills through adoption of the Industrial Development Policy 2015-2025 and the National Employment Policy 2015-2025. These policies aim at transforming Cambodia's economic structure and creating decent work, ensuring quality and high productivity of the workforce. To support and complement these goals, the new National TVET Policy presents a vision, goals, objectives, and strategies to develop human resources with high quality, competency, and skills that can promote socioeconomic development today and in the future. 


\section{Technical and Vocational Education and Training Policy Vision}

To improve people's livelihood and dignity and to enhance Cambodia's human resources with knowledge, competency, skills, working attitudes, professional ethics, productivity, and competitiveness for lifelong employability.

\section{WHAT ARE THE POLICY GOALS AND OBJECTIVES?}

To achieve the vision (see box) the policy defines four related goals: ${ }^{3}$

(i) to improve TVET quality to meet national and international market demand;

(ii) to increase equitable access to TVET;

(iii) to promote public-private partnerships (PPPs) and aggregate stakeholder resources to support sustainable development of the TVET system; and

(iv) to improve governance of the TVET system.

The policy adopts several detailed objectives under each goal.

\section{Goal 1. Improve TVET quality to meet national and international market demand}

- Continue to develop and implement a quality assurance system based on the Cambodia Qualification Framework.

- Improve trainer quality, pedagogy, and infrastructure including training and learning resources in response to current technology development and labor market demand.

- Establish technical and vocational parks in industrial or economic zones to maximize use of equipment and trainers.

\section{Goal 2. Increase equitable access to TVET}

- Increase enrolment in the TVET system by providing flexible pathways to entry.

- Expand opportunities for people to obtain life skills by paying special attention to the needs of women, marginalized groups, poor youth, school dropouts, migrant workers, and indigenous people.

- Enhance all means and mechanisms to expand TVET based on the qualification framework for all training institutions and stakeholders.
- Increase awareness of the TVET system by providing career guidance and vocational skills, and through institutional outreach and marketing.

- Establish a one-stop service and provide convenient services related to TVET.

\section{Goal 3. Promote PPPs and aggregate stakeholder resources to support sustainable development of TVET System}

- Enhance PPPs with TVET stakeholders.

- Expand PPPs to develop training curriculum based on market needs to strengthen skills that respond to new and existing technology.

- Establish coordination mechanisms with stakeholders to set up a national skills development fund.

- Develop a student fee policy for TVET providers and offer scholarships for poor students, women, and indigenous people.

\section{Goal 4. Improve governance of the TVET system}

- Strengthen the regulatory framework for TVET to link skills training to labor market demand.

- Develop a results-based funding mechanism for operating TVET institutions.

- Continue to improve the TVET management information system, the labor market information system, and strengthen labor market forecasting and assessment of skills needs.

\section{HOW WILL THE POLICY BE MONITORED?}

The National Training Board of the Ministry of Labour and Vocational Training acts as secretariat, tasked with coordinating implementation and monitoring and evaluation of the policy. The National Training Board will prepare annual reports to identify progress and challenges based on the detailed objectives and indicators.

\section{LOOKING AHEAD TO 2025: ENHANCING SKILLS, INCREASING COMPETITIVENESS}

The TVET policy is a much-needed road map to guide further development of the country's training system that provides skills, capacities, and employment-related knowledge to Cambodia's people. The policy will support lifelong education and employment with the aim of improving workers' productivity and competitiveness. This is a challenge both in the region and globally, particularly in the context of the regional economic integration envisioned under the Association of Southeast Asian Nations Economic Community.

3 Policy goals and objectives are directly quoted from the national TVET policy document, and detailed strategies for each objective are described in the policy document. For the full policy document, see the link: http://www.mlvt.gov.kh/index.php/en/policies-and-plan/58 
The timing to implement this policy is right as Cambodia aspires to become a middle-income country by 2030 . The current focus on improving the skills of Cambodia's workforce is essential, with particular attention to the large number of unemployed youth with limited education and school dropouts who cannot access formal TVET.

The new policy's emphasis on close partnerships between employer and employee associations, development partners, and training providers is crucial as Cambodia continues to attract foreign investment requiring skilled workers and offering higher wages.

As one of the country's leading development partners in education and skills, ADB looks forward to contributing to the achievement of the policy's goals through its ongoing and future investments in education, TVET, and ultimately, in Cambodia's prosperous future.
About the Asian Development Bank

ADB's vision is an Asia and Pacific region free of poverty. Its mission is to help its developing member countries reduce poverty and improve the quality of life of their people. Despite the region's many successes, it remains home to a large share of the world's poor. ADB is committed to reducing poverty through inclusive economic growth, environmentally sustainable growth, and regional integration.

Based in Manila, ADB is owned by 67 members, including 48 from the region. Its main instruments for helping its developing member countries are policy dialogue, loans, equity investments, guarantees, grants, and technical assistance.
The views expressed in this publication are those of the authors and do not necessarily reflect the views and policies of ADB or its Board of Governors or the governments they represent.

Asian Development Bank

6 ADB Avenue, Mandaluyong City

1550 Metro Manila, Philippines

Tel +6326324444

Fax +6326362444

www.adb.org/publications/series/adb-briefs

ADB Briefs are based on papers or notes prepared by ADB staff and their resource persons. The series is designed to provide concise, nontechnical accounts of policy issues of topical interest, with a view to facilitating informed debate. The Department of Communications administers the series.

\section{(C) (1)}

Creative Commons Attribution 3.0 IGO license (CC BY 3.0 IGO)

(C) 2018 ADB. The CC license does not apply to non-ADB copyright materials in this publication.

https://www.adb.org/terms-use\#openaccess http://www.adb.org/publications/corrigenda pubsmarketing@adb.org 